\title{
The Influence of Porosity on Mechanical Properties of Casts Produced from Al - Si Alloys
}

Radek Honzátko, Štefan Michna, Jaromír Cais

Faculty of Production Technology and Mamagement, Department of Technology and Material Engineering, Jan Evangelista Purkyně University in Ústí nad Labem, Na Okraji 1001, 40001 Ústí nad Labem, Czech Republic, e-mail: michna@fvtm.ujep.cz

The aim of the research was to evaluate influence of porosity size on mechanical properties of AISi7Mg0.3 (EN AC 42 100) alloy before and after thermal treatment. For the analyses casts of the same production type (forms used for tires production) were used. They were casted employing low-pressure casting technology. Since the negative influence of porosity on mechanical properties of $\mathrm{Al}$ alloys is generally known there is no quantitative assessment. In this research relation of porosity size in the structure of AlSi7Mg0.3 alloy and its mechanical properties is verified and quantified. Static tensile testing has proven the relation between porosity size in a structure of an Al material and its mechanical properties. Image analysis was applied in quantitative measurement of the porosity. The measurement was performed on prepared metallographic specimens. Porosity size is considered as a fraction of pore area to the total area of the analyzed specimen and is taken in percentage.

Keywords: porosity, gassing, AlSi7Mg0.3 alloy, mechanical properties, intermetallic phases

\section{References}

[1] GRÍGEROVÁ, T. a kol.: Zlivárenstvo neželezných kovov, 1988, ALFA Bratislava, SNTL Praha, ZNK 063-56688.

[2] MONDOLFO, L. F.: Aluminium Alloys, Structure and Properties, Butterworths, London 1979.

[3] MICHNA, Š.: Identifikace vad u Al-slitin ve slévárenském procesu., Transactions of the Technical Univerzity of Košice 4/97, ISSN 1335-2334.

[4] BOLIBRUCHOVÁ, D., TILLOVÁ, E.: Zlievárenské zliatiny Al-Si, ŽU v Žiline - EDIS, 2005, ISBN 80-8070485-6.

[5] MICHNA, Š., LUKÁČ, I. a kol.: Encyklopedie hliníku, 720 str., Adin s.r.o., Prešov SR, 2005, ISBN 80-8904188-4.

[6] MICHNA, S, LUKÁC, I.: Barevny kontrast, struktury a vady u hliniku a jeho slitin, 214 str. Delta Print, Dečín ČR, ISBN 80-239-1636-X.

[7] LUKÁČC, I., MICHNA, S.: Colour Contrast, Structure and Defects in Aluminium and Aluminium Alloys.

[8] MICHNA, S., KUŚMIERCZAK, S.: Praktická metalografie, UJEP v Ústí nad Labem 2012, ISBN 978-807414-503-2

[9] NOVÁ, I., SOLFRONK , P., NOVÁKOVÁ, I.: Vliv množství dislokací na tvařitelnost slitin hliníku, Strojírenská technologie, XVI/2, r. 2011, str. 28-34, ISSN 1211-4162.

[10] VAJSOVÁ, V.: Structural inhomogeneity by Al-Cu alloys casting into metal and bentonic form. Transactions of the Universities of Košice, r. 2009, č. 1., ISSN 1355-2334.

[11] MICHNA, Š., NÁPRSTKOVÁ, N., LUKÁČ I.: Mechanical Properties Optimization of AlSi12CuMgNi Alloy by Heat Treatment. Metallofizika i Noveishie Teknologii, 11/2011, ISSN 1024-1809.

[12] VAJSOVÁ, V., MICHNA, Š.: Optimization of AlZn5,5Mg2,5Cu1,5 Alloy Homogenizing Annealing. Metallofizika i Noveishie Teknologii, Volume 32, No 7, July 2010, str. 949 - 959, ISSN 1024-1809.

[13] MICHNA, Š., MAJRICH, P.: An analysis of the Process of Melting Food Packaging and Acquiring the Aluminium Alloy, Металлург, 11/2012, ISSN 0026 - 0827 (IMPACT).

[14] MICHNA, S., NÁPRSTKOVÁ, N.: Research into the causes cracking of aluminum alloys of Al-Cu during mechanical machining, Manufacturing Technology, vol. 12, No. 12, June 2012, str. 47-51, ISSN 1213-2489.

[15] MICHALCOVÁ, A., VOJTĚCH, D.: Structure of rapidly solidified aluminum alloys, Manufacturing Technology, vol. 11, No. 13, December 2012, ISSN 1213-2489.

[16] MICHNA, Š., NÁPRSTKOVÁ, N.: The use of fractography in the analysis of cracking after formel workpiece blank mechanical machining from the AlCuSnBi alloy, Manufacturing Technology, vol. 11, No. 13, December 2012, ISSN 1213-2489. 